\title{
An Overview of the Helminths of Moor Frog Rana arvalis Nilsson, 1842 (Amphibia: Anura) in the Volga Basin
}

\author{
Igor V. Chikhlyaev ${ }^{1}$ and Alexander B. Ruchin ${ }^{2, *(D)}$ \\ 1 Samara Federal Research Scientific Center RAS, Institute of Ecology of Volga River Basin RAS, 10 Komzina \\ Street, 445003 Togliatti, Russia; diplodiscus@mail.ru \\ 2 Joint Directorate of the Mordovia State Nature Reserve and National Park "Smolny", 30 Krasnaya Street, \\ 430005 Saransk, Russia \\ * Correspondence: ruchin.alexander@gmail.com
}

Citation: Chikhlyaev, I.V.; Ruchin, A.B. An Overview of the Helminths of Moor Frog Rana arvalis Nilsson, 1842 (Amphibia: Anura) in the Volga Basin. Diversity 2021, 13, 61. https:// doi.org/10.3390/d13020061

Academic Editors: Ulrich Sinsch and Miguel Ferrer

Received: 30 November 2020

Accepted: 28 January 2021

Published: 4 February 2021

Publisher's Note: MDPI stays neutral with regard to jurisdictional claims in published maps and institutional affiliations.

Copyright: (c) 2021 by the authors. Licensee MDPI, Basel, Switzerland. This article is an open access article distributed under the terms and conditions of the Creative Commons Attribution (CC BY) license (https:// creativecommons.org/licenses/by/ $4.0 /)$.

\begin{abstract}
This is the first review of the helminth fauna of the moor frog Rana arvalis Nilsson, 1842 from the Volga river basin (Russia). The article summarizes the authors' and literature data on the helminthic fauna of this species. The method of complete helminthological dissection was used. Thirthy-eight helminth species were recorded from three classes: Cestoda (1), Trematoda (28), and Chromadorea (9). Nine helminth species are new to the moor frog in Russia: trematodes Gorgodera varsoviensis Sinitzin, 1905, Strigea falconis Szidat, 1928, larvae, Neodiplostomum spathoides Dubois, 1937, larvae, Tylodelphys excavata (Rudolphi, 1803), larvae, Pharyngostomum cordatum (Diesing, 1850), larvae, Astiotrema monticelli Stossich, 1904, larvae and Encyclometra colubrimurorum (Rudolphi, 1819), larvae, nematodes Strongyloides spiralis Grabda-Kazubska, 1978 and Icosiella neglecta (Diesing, 1851). The cestode Spirometra erinacei (Rudolphi, 1918), larvae were observed of this amphibian species in the Volga basin for the first time. The nematodes Rhabdias bufonis, Oswaldocruzia filiformis, Cosmocerca ornata and the trematode Haplometra cylindracea form the core of the helminth fauna of the moor frog. Information on species of helminths includes systematic position, localization, areas of detection, type and scheme of life cycle, geographical distribution, and degree of specificity to host amphibians.
\end{abstract}

Keywords: helminthes; cestodes; trematodes; nematodes; moor frog; Rana arvalis; The Volga river basin

\section{Introduction}

In recent decades, the study of amphibian parasites has become more relevant. This is due to the crisis that this group of vertebrates is experiencing. Amphibian populations are sharply declining around the world [1-3]. About a third (32.4\%) of the world's amphibian species are on the verge of extinction [4]. The disappearance, degradation, and pollution of habitats as a result of anthropogenic activities are the main factors contributing to the reduction of the range and abundance of many species [5-8]. There are constant reports of amphibian diseases caused by viruses [9,10], bacteria [11], mycos [12-14], and helminths.

The pathogenic effect of helminthic invasion on amphibians has a wide range of manifestations: from cellular changes to inhibition of behavioral reactions. Trematodes play an important role in these processes. For example, multiple clusters of Holostephanus volgensis cysts during the metamorphosis of moor frog larvae cause the appearance of skeletal anomalies [15]. Cercariae of the genus Ribeiroia lead to limb malformations in tadpoles of North American amphibians [16-18]. The formation of deviant forms of skeletal elements significantly reduces the survival rate of the young generation of amphibians and facilitates their consumption by predators. Another type of pathology is a violation of the functioning of the internal organs of the hosts, leading to their death. For example, multiple renal invasion by Echinostoma and Echinoparyphium metacercariae contributes to the development of edema and renal failure [18]. The concentration of Pleurogenes hepaticola in the bile ducts of the green frog causes liver cirrhosis and enlargement and deformation of bile-ducts 
and gall-bladder [19,20]. Metacercariae Codonocephalus urnigerus, when intensely infested, causes pathological changes in the gonads (ovarian dystrophy, testicular tumors) in the moor frog and lead to parasitic castration of the hosts. In infected individuals, food reflexes, sexual instincts, territorial and migration behavior are suppressed. Such individuals do not participate in the breeding process, do not respond to threats, are inactive, and become easy prey for predators [21]. Localization of Brandesia turgida in the duodenum of Pelophylax ridibundus is accompanied by granulomatous inflammation of its serous membrane with the development of a clinical picture of histological and cytological pathologies [22].

The moor frog, Rana arvalis Nilsson, 1842 is a widely distributed Eurasian species ranging from the Eastern France in the west to the Baikal Lake in the east and from Kola Peninsula in the north to the southern part of the Pannonian Basin [23]. This species lives in a wide variety of natural and anthropogenic biotopes. It is found in various types of forests, swamps, meadows, and pastures, in ravines, near streams and rivers, and it inhabits rural areas and suburban parks [24-27]. The moor frog is resistant to freezing, which is the reason for its wide distribution [28].

Parasitologists from Sweden [29], Denmark [30], Germany [31-33], Poland [34-37], Hungary [38] and the former Czechoslovakia [39-45] studied helminths of the moor frog in Europe. Similar studies were carried out in the republics of the former USSR [46], for example, in Belarus [47-50]. According to the latest reports [51-53], 47 species of helminths of five groups have been registered in this host in Europe: monogeneans (1 species), cestodes (1), trematodes (26), nematodes (18), and acanthocephales (1). The species of six of them have not been identified. Later, a representative of another class of helminths, leeches, was found [54].

The Volga is the longest river in Europe. Its length is $3690 \mathrm{~km}$ and the basin area is about 1.4 million $\mathrm{km}^{2}$. It occupies 33\% of the territory of European Russia and almost $13 \%$ of Europe. It flows through different types of biomes from taiga in the North to semi-desert in the South [55]. The Volga basin includes total or part of the territory of 38 regions of Russia [56], which are home to 13 species of tailless and tailed amphibians, including 2 species of brown frogs (genus Rana): Rana temporaria Linnaeus, 1758 and R. arvalis [57].

In contrast to other frogs, whose helminthic fauna was studied in detail earlier in the Volga basin [58-61], data on helminths of moor frog remain scattered. Prior to this research, there was no summary on the helminths of $R$. arvalis, which inhabit the Volga river basin. Such a paper is needed due to the abundance of such information, changes in the systematics of helminths, and the long-term nature of the observations. The first information on this issue was obtained in the second half of the last century in the Republics of Bashkortostan [62,63], Tatarstan [64,65], and the Nizhny Novgorod (former Gorky region) region [66-69]. Some of these studies are presented in the monograph of K. M. Ryzhikov et al. [46], which was then included in the European reports [52,53]. In the last 15 years, new information has become available from the Vologda, Ivanovo, Samara and Saratov regions, the Republic of Mordovia, and data from the Republic of Bashkortostan has been updated. This publication is the first review of the $R$. arvalis helminth fauna from populations in the Volga river basin (Russia).

Study area: This study is based on the results of our own research, as well as on the data of other authors for the period from 1974 to 2020. The material for the study was personal fees and information about helminths from 990 specimens of moor frogs from eight regions of the Volga basin: Vologda, Ivanovo, Nizhny Novgorod, Samara and Saratov regions, the Republics of Mordovia, Tatarstan, and Bashkortostan (Figure 1). 


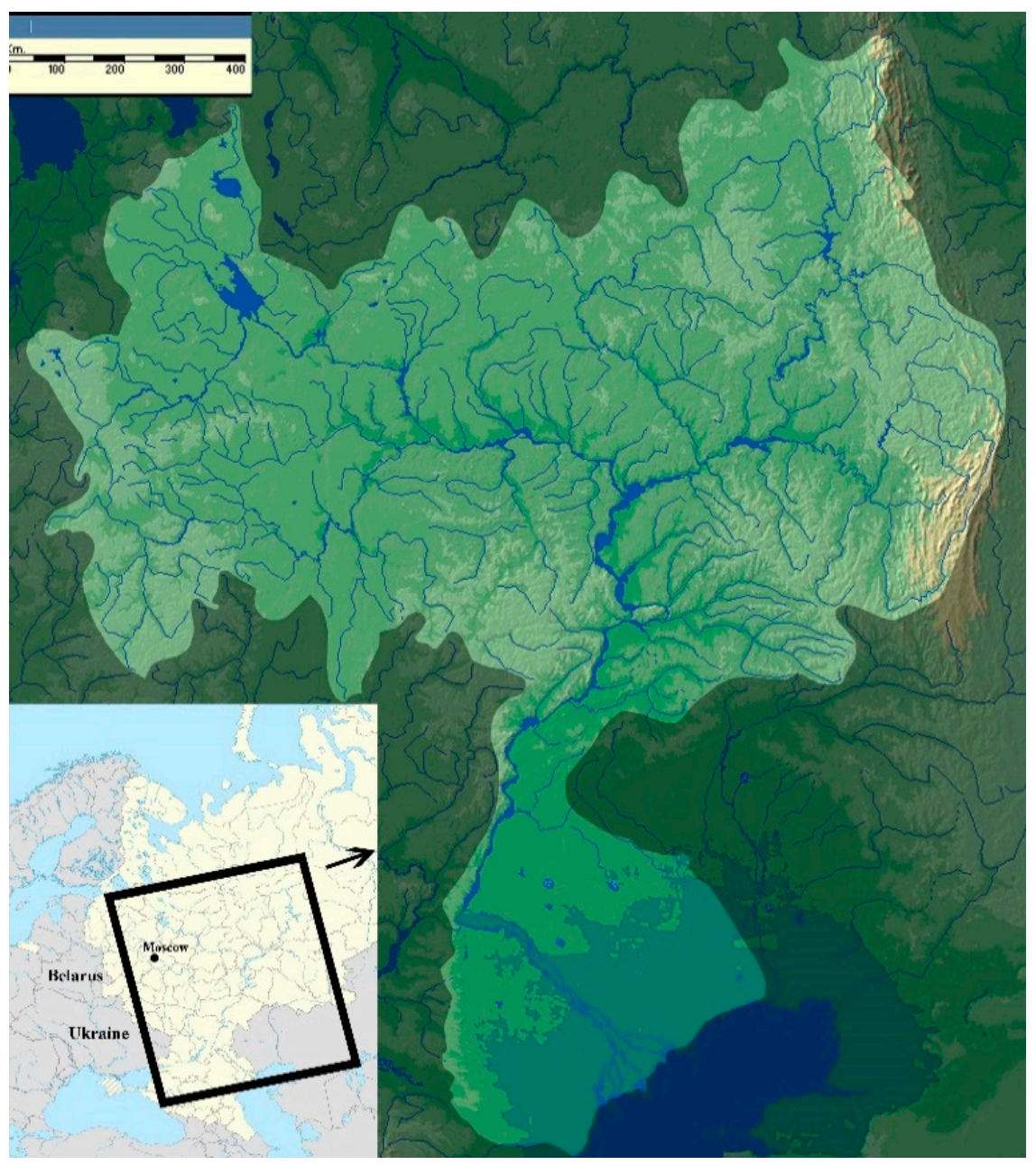

Figure 1. Location of the Volga basin.

The method of complete helminthological dissection was used. Collection, fixation and processing of helminthological material were performed by standard methods. Trematodes and cestodes were immobilized by heating, fixed with $70 \%$ ethanol under pressure, and stained with alum carmine and encased in Canadian balsam. A dimethyl phthalate solution was used to enlighten flatworms. The nematodes were straightened by heat and fixed with Barbagallo liquid ( $3 \%$ formalin solution in $\mathrm{NaCl}$ saline). Nematodes were studied both on temporary vouchers with enlightenment in lactic acid, and on total vouchers with the conclusion in glycerol-gelatin. Own vouchers of worms and partially amphibian hosts are stored in Parasitological and Herpetological collections of the Institute of Ecology of Volga Basin of RAS, Samara Federal Research center Russian Academy of Sciences, Togliatti, Russia. The species of helminths was identified according to the determinants of K. M. Ryzhikov et al. [46] and V. E. Sudarikov et al. [70]. The systematics of helminths is based on modern data on trematodes [71-74] and nematodes [75]. For describing the intermediate hosts of trematodes and cestodes, data was used from the website "Fauna Europaea" (http:/ / www.faunaeur.org (accesssed on 3 February 2021)) [76].

There is an annotated list of species of the moor frog helminths inhabiting protected and transformed biocoenoses of the Volga river basin (Appendix A). It includes the systematic position and localization of the parasite, the areas of detection, and geographical distribution.

\section{Results}

The helminth fauna of the moor frog $R$. arvalis in the Volga river basin includes 38 species of helminths. Systematically, they belong to 30 genera, 16 families, 7 orders, 
and 3 classes: Cestoda-1, Trematoda-28, and Chromadorea-9 (Table 1). Nine helminth species are new to this host in Russia: trematodes-Gorgodera varsoviensis Sinitzin, 1905, Strigea falconis Szidat, 1928, larvae, Neodiplostomum spathoides Dubois, 1937, larvae, Tylodelphys excavata (Rudolphi, 1803), larvae, Pharyngostomum cordatum (Diesing, 1850), larvae, Astiotrema monticelli Stossich, 1904, larvae иEncyclometra colubrimurorum (Rudolphi, 1819), larvae, nematodes-Strongyloides spiralis Grabda-Kazubska, 1978 иIcosiella neglecta (Diesing, 1851). Another cestode species Spirometra erinacei (Rudolphi, 1918), larvae, was first recorded in a moor frog in the Volga basin.

Table 1. Helminths of a moor frog Rana arvalis in the Volga basin regions.

\begin{tabular}{|c|c|c|c|c|c|c|c|c|}
\hline Helminths Species & VL & IV & NN & SM & SR & MR & TT & BS \\
\hline Spirometra erinacei, larvae & & & & & & + & & \\
\hline Halipegus ovocaudatus & & & & & & & + & \\
\hline Diplodiscus subclavatus & & & + & + & & + & + & + \\
\hline Gorgodera cygnoides & & & & & & + & + & + \\
\hline Gorgodera microovata & & & + & & & + & & \\
\hline Gorgodera pagenstecheri & & & + & & & + & & \\
\hline Gorgodera varsoviensis & & & & + & & & & \\
\hline Gorgoderina vitelliloba & & & + & & & + & & + \\
\hline Haplometra cylindracea & + & + & + & + & + & + & & + \\
\hline Dolichosaccus rastellus & & & & + & + & + & & + \\
\hline Opisthioglyphe ranae & & & + & + & & + & + & + \\
\hline Haematoloechus variegatus & & + & & + & & + & & + \\
\hline Haematoloechus asper & + & & + & & & & & \\
\hline Skrjabinoeces similis & & & & + & + & & & + \\
\hline Brandesia turgida & & & & & & & & + \\
\hline Pleurogenes claviger & & & & + & & + & & + \\
\hline Pleurogenes intermedius & & & & + & & + & & + \\
\hline Pleurogenoides medians & + & & + & & & + & & + \\
\hline Prosotocus confusus & & & + & + & & & & + \\
\hline Paralepoderma cloacicola, larvae & & & & + & + & + & & \\
\hline Strigea strigis, larvae & & & & + & + & + & & + \\
\hline Strigea sphaerula, larvae & & & & + & & + & & + \\
\hline Strigea falconis, larvae & & & & + & & + & & \\
\hline Neodiplostomum spathoides, larvae & & & & + & & + & & \\
\hline Tylodelphys excavata, larvae & & & & + & & & & \\
\hline Alaria alata, larvae & & & & + & + & + & & + \\
\hline Pharyngostomum cordatum, larvae & & & & + & & & & \\
\hline Astiotrema monticelli, larvae & & & & + & & + & & \\
\hline Encyclometra colubrimurorum, larvae & & & & + & + & & & \\
\hline Rhabdias bufonis & + & + & + & + & + & + & + & + \\
\hline Strongyloides spiralis & & & & + & & & & \\
\hline Oswaldocruzia filiformis & + & + & + & + & + & + & + & + \\
\hline Aplectana acuminata & + & + & + & & & & + & + \\
\hline Cosmocerca ornata & + & + & + & + & + & + & + & + \\
\hline Cosmocerca commutata & & & + & & & & + & + \\
\hline Neoraillietnema praeputiale & & & + & & & + & & \\
\hline Oxysomatium brevicaudatum & & & + & & & + & & + \\
\hline Icosiella neglecta & & & & & & + & & \\
\hline Species in total & 7 & 6 & 16 & 24 & 10 & 26 & 9 & 22 \\
\hline Cestoda & - & - & - & - & - & 1 & - & - \\
\hline Trematoda & 3 & 2 & 9 & 20 & 7 & 19 & 4 & 16 \\
\hline Chromadorea & 4 & 4 & 7 & 4 & 3 & 6 & 5 & 6 \\
\hline Examined, specimens & 8 & 35 & 95 & 138 & 15 & 325 & 126 & 248 \\
\hline
\end{tabular}

Notes: VL—Vologda region; IV—Ivanovo region; NN—Nizhny Novgorod region; SM—Samara region; SR—Saratov region; MR—The Republic of Mordovia; TT-The Republic of Tatarstan; BS-The Republic of Bashkortostan. 
According to the degree of hostal specificity, all species of helminths are divided into 3 groups. Most of them (23 species) are polyhostal parasites of tailless amphibians. A minority (14) are oligohostal for frogs of the family Ranidae. Another nematode species, Cosmocerca commutata (Diesing, 1851), is a monohostal parasite of the green toad (Bufotes viridis Laurenti, 1768).

The moor frog serves as the definitive host for most helminth species (22), which parasitize exclusively at the adult stage of development (Table 1). For some cestode (1) and trematode (10) species that parasitize at the larval stage, the amphibian is an intermediate, intercalary (mesocercarial), additional (metacercarial), and/or paratenic (metacercarial) host. The remaining 5 species of trematodes (G. vitelliloba, H. cylindracea, D. rastellus, O. ranae) and nematode (C. commutata) combine the larval and adult stages of development in the amphibian body. In relation to such helminths, the moor frog plays the role of an amphixenic host. Brief information on the biology of helminths with the indication of host categories is given in Table 2.

Table 2. Life cycles of helminths of a moor frog Rana arvalis.

\begin{tabular}{|c|c|c|}
\hline Helminths Species & Life Cycle & Citation \\
\hline Spirometra erinacei, larvae & $\begin{array}{c}\text { cyclops (Cyclopidae) }{ }^{1} \text {-frogs, snakes, rodents }{ }^{3} \text {-crows, mammals } \\
\text { (Eulipotyphla, Mustelidae) }{ }^{4} \text {-predatory mammals }{ }^{5} \text { (Canidae, Felidae) }\end{array}$ & [77] \\
\hline Halipegus ovocaudatus & $\begin{array}{c}\text { gastropods (Planorbidae) }{ }^{1} \text {-cyclops }(\text { Cyclopidae })^{3} \text {-dragonflies } \\
\text { (Calopterygidae, Coenagrionidae, Lestidae, Libellulidae) }{ }^{3} \text {-amphibians } \\
(\text { Amphibia })^{5}\end{array}$ & [78] \\
\hline Diplodiscus subclavatus & gastropods (Planorbidae) ${ }^{1}$-amphibians (Amphibia) ${ }^{5}$ & {$[79,80]$} \\
\hline Gorgodera cygnoides & bivalves (Sphaeriidae) ${ }^{1}$-dragonflies (Corduliidae) ${ }^{3}$-frogs (Ranidae) ${ }^{5}$ & {$[81]$} \\
\hline Gorgodera microovata & unknown & \\
\hline Gorgodera pagenstecheri & $\begin{array}{l}\text { bivalves (Sphaeriidae) }{ }^{1} \text {-dragonflies (Calopterygidae, Corduliidae), caddis } \\
\left.\text { flies (Limnephilidae) }{ }^{3} \text {-frogs (Ranidae) }\right)^{5}\end{array}$ & {$[81]$} \\
\hline Gorgodera varsoviensis & $\begin{array}{c}\text { bivalves (Sphaeriidae) }{ }^{1} \text {-dragonflies (Calopterygidae), caddis flies } \\
\left.\text { (Limnephilidae) }^{3} \text {-frogs (Ranidae) }\right)^{5}\end{array}$ & [81] \\
\hline Gorgoderina vitelliloba & bivalves (Sphaeriidae) ${ }^{1}$-tadpoles, alderflies ${ }^{3}$-anurans (Anura) ${ }^{5}$ & {$[40,82,83]$} \\
\hline Haplometra cylindracea & gastropods (Lymnaeidae) ${ }^{1}$-tadpoles (Anura) ${ }^{3}$-anurans (Anura) ${ }^{5}$ & {$[84,85]$} \\
\hline Dolichosaccus rastellus & gastropods (Lymnaeidae) ${ }^{1}$-tadpoles (Anura) ${ }^{3}$-anurans (Anura) ${ }^{5}$ & {$[83,86]$} \\
\hline Opisthioglyphe ranae & $\begin{array}{c}\text { gastropods (Lymnaeidae) }{ }^{1} \text {-gastropods (Lymnaeidae), tadpoles (Anura) } \\
{ }^{3} \text {-anurans (Anura) }{ }^{5}\end{array}$ & {$[86,87]$} \\
\hline Paralepoderma cloacicola, larvae & gastropods (Planorbidae) ${ }^{1}$-anurans (Anura) ${ }^{3}$-snakes (Colubridae) ${ }^{5}$ & {$[88,89]$} \\
\hline Haematoloechus variegatus & $\begin{array}{l}\text { gastropods (Planorbidae) }{ }^{1} \text {-mosquitos (Culicidae), dragonflies } \\
\text { (Calopterygidae, Libellulidae) }^{3} \text {-anurans (Anura) }\end{array}$ & {$[90,91]$} \\
\hline Haematoloechus asper & $\begin{array}{l}\text { gastropods (Planorbidae) }{ }^{1} \text {-dragonflies (Calopterygidae, Lestidae) } \\
{ }^{3} \text {-anurans (Anura) }{ }^{5}\end{array}$ & {$[92]$} \\
\hline Skrjabinoeces similis & $\begin{array}{c}\text { gastropods (Planorbidae) }{ }^{1} \text {-dragonflies (Aeshnidae, Calopterygidae, } \\
\text { Coenagrionidae, Corduliidae, Lestidae, Libellulidae) }{ }^{3} \text {-frogs (Ranidae) }{ }^{5}\end{array}$ & [93] \\
\hline Brandesia turgida & unknown & \\
\hline Pleurogenes claviger & $\begin{array}{l}\text { gastropods (Bithyniidae) }{ }^{1} \text {-dragonflies, bugs, mayflies, caddis flies, } \\
\text { alderflies, crustaceans (Gammaridae, Asellidae) }{ }^{3} \text {-anurans (Anura) }{ }^{5}\end{array}$ & {$[94,95]$} \\
\hline Pleurogenes intermedius & unknown & \\
\hline Pleurogenoides medians & $\begin{array}{l}\text { gastropods (Bithyniidae) }{ }^{1} \text {-dragonflies, bugs, mayflies, caddis flies, } \\
\text { alderflies, mosquitos, crustaceans (Gammaridae, Asellidae) }{ }^{3} \text {-anurans } \\
\text { (Anura })^{5}\end{array}$ & {$[94,96]$} \\
\hline Prosotocus confusus & $\begin{array}{c}\text { gastropods (Bithyniidae) }{ }^{1} \text {-dragonflies, bugs, caddis flies, alderflies, } \\
\text { crustaceans (Gammaridae) }{ }^{3} \text {-anurans (Anura) }{ }^{5}\end{array}$ & {$[94,97]$} \\
\hline
\end{tabular}


Table 2. Cont.

\begin{tabular}{|c|c|c|}
\hline Helminths Species & Life Cycle & Citation \\
\hline Strigea strigis, larvae & $\begin{array}{c}\left.\text { gastropods (Planorbidae) }{ }^{1} \text {-tadpoles (Anura) }{ }^{2} \text {-anurans (Anura) }\right)^{3,4} \text {-snakes } \\
{\text { (Colubridae), mammals (Eulipotyphla, Mustelidae, Canidae) }{ }^{4} \text {-owls }}^{\text {(Strigiformes) }}{ }^{5}\end{array}$ & [98-101] \\
\hline Strigea sphaerula, larvae & $\begin{array}{l}\left.\text { gastropods (Planorbidae })^{1} \text {-tadpoles (Anura) }{ }^{2} \text {-anurans (Anura) }\right)^{3,4} \text {-snakes } \\
\left.\text { (Colubridae) }{ }^{4} \text {-crows (Corvidae), warblers (Acrocephalidae) }\right)^{5}\end{array}$ & {$[98,99,101-103]$} \\
\hline Strigea falconis, larvae & $\begin{array}{c}\left.\text { gastropods (Planorbidae) }{ }^{1} \text {-tadpoles (Anura) }{ }^{2} \text {-anurans (Anura) }\right)^{3,4} \text {-snakes } \\
\text { (Colubridae), mammals (Eulipotyphla, Mustelidae, Canidae) }{ }^{4} \text {-birds of } \\
\text { prey (Accipitriformes, Falconiformes) }\end{array}$ & {$[98,101,104]$} \\
\hline $\begin{array}{l}\text { Neodiplostomum spathoides, } \\
\text { larvae }\end{array}$ & $\begin{array}{l}\text { gastropods (Planorbidae) }{ }^{1} \text {-frogs (Anura) }{ }^{3} \text {-snakes (Colubridae), crows, } \\
\text { seagulls, ducks }{ }^{4} \text {-birds of prey (Accipitriformes, Falconiformes) }\end{array}$ & [105-107] \\
\hline Tylodelphys excavata, larvae & $\begin{array}{l}\text { gastropods (Planorbidae) }{ }^{1} \text {-frogs (Anura) }{ }^{3} \text {-long-legged birds } \\
\text { (Ciconiiformes), buzzards (Accipitriformes) }\end{array}$ & {$[105,108]$} \\
\hline Alaria alata, larvae & $\begin{array}{c}\text { gastropods (Planorbidae) }{ }^{1} \text {-anurans (Anura) }{ }^{2} \text {-frogs, snakes, crows, } \\
\text { seagulls, ducks, owls, birds of prey, rodents, insectivorous and predatory } \\
\text { mammals }{ }^{4} \text {-canids (Canidae) }{ }^{5}\end{array}$ & [109-111] \\
\hline $\begin{array}{l}\text { Pharyngostomum cordatum, } \\
\text { larvae }\end{array}$ & $\begin{array}{l}\text { gastropods (Planorbidae) }{ }^{1} \text {-frogs (Ranidae) }{ }^{3} \text {-snakes, crows, rodents, } \\
\text { insectivorous and predatory mammals }{ }^{4} \text {-predatory mammals (Canidae, } \\
\text { Felidae) }{ }^{5}\end{array}$ & {$[111,112]$} \\
\hline Astiotrema monticelli, larvae & $\begin{array}{c}\text { gastropods (Bithyniidae) }{ }^{1} \text {-anurans (Anura) }{ }^{3} \text {-snakes (Colubridae, } \\
\text { Viperidae) })^{5}\end{array}$ & {$[113,114]$} \\
\hline $\begin{array}{l}\text { Encyclometra colubrimurorum, } \\
\text { larvae }\end{array}$ & $\begin{array}{c}\text { gastropods (unknown) }{ }^{1} \text {-anurans (Anura) }{ }^{3} \text {-snakes (Colubridae, } \\
\text { Viperidae) }\end{array}$ & [114] \\
\hline Rhabdias bufonis & soil-oligochaetes, gastropods ${ }^{4}$-anurans (Anura) ${ }^{5}$ & {$[33,115,116]$} \\
\hline Strongyloides spiralis & unknown & \\
\hline Oswaldocruzia filiformis & soil-amphibians (Amphibia) ${ }^{5}$ & [117-119] \\
\hline Aplectana acuminata & unknown & \\
\hline Cosmocerca ornata & water-anurans (Anura) ${ }^{5}$ & {$[120,121]$} \\
\hline Cosmocerca commutata & soil-anurans (Anura) ${ }^{1,5}$ & {$[122,123]$} \\
\hline Oxysomatium brevicaudatum & soil-anurans (Anura) ${ }^{5}$ & {$[118,122]$} \\
\hline Neoraillietnema praeputiale & unknown & \\
\hline Icosiella neglecta & wood lice (Ceratopogonidae) ${ }^{1}$-frogs (Ranidae) ${ }^{5}$ & {$[124,125]$} \\
\hline
\end{tabular}

The largest number of helminth species has been recorded in the moor frog from the Republic of Mordovia (26 species), the Samara region (24), and the Republic of Bashkortostan (22); the smallest number has been recorded in the Republic of Tatarstan (9), Vologda (7), and Ivanovo (6) regions. The same indicator for this host in the Nizhny Novgorod (16) and Saratov (10) regions is characterized by intermediate values (Table 1). The reasons for the differences are usually complex: from the different number of amphibians studied in a particular region to the biotopic differences in their habitats, types of biomes, geographical location, climate, and the degree of anthropogenic impact. It is difficult to carry out statistical processing of data that were obtained by different authors at different times and in different seasons. However, even on the basis of the mentioned information, conclusions can be drawn. It is not only the intensive study of helminth fauna that has affected the list of species in recent years. For example, the number of materials studied was similar in the Republic of Mordovia and the Republic of Tatarstan. However, the species richness of helminths differed significantly. We think that this depends on the geographical and 
climatological characteristics of the range of $R$. arvalis. The Republic of Tatarstan has a more continental climate, which influences the activity of amphibians.

The composition of helminths of the moor frog differs in certain regions of the Volga basin. Comparative analysis shows that only three species out of 38 were found in all samples: the nematodes Rh. bufonis, O. filiformis, and C. ornata. Among trematodes, the most widespread species is $H$. cylindracea, which has been recorded in seven regions. This group of helminth species (4) forms the core of the helminth fauna of the moor frog in the Volga river basin. Largest group of species (26) are common parasites of this host, occurring sporadically: in five (3 species), four (6), three (9), and two (8) regions. The last 8 species of cestodes (S. erinacei, larvae), trematodes (H. ovocaudatus, G. varsoviensis, $B$. turgida, T. excavata, larvae, Ph. cordatum, larvae) and nematodes (S. spiralis and I. neglecta), belong to the group of rare or accidental parasites of the moor frog and have a strict local confinement (Table 1).

\section{Discussion}

The biology and ecology of the moor frog is characterized by a number of life-history traits: (1) active terrestrial lifestyle in wet forest, forest-steppe, and even steppe stations; (2) feeding on terrestrial invertebrates (oligochaetes, mollusks, insects, millipedes, arachnids); (3) visiting ponds and lakes during spawning; (4) "mating fasting". The range of $R$. arvalis in the Volga basin is extensive and the habitats are extremely diverse [126].

These factors determine the species composition, structure and community of the helminth fauna in this frog, distinguishing 3 groups of parasite species. The first group (18 species) includes adult biohelminths (trematodes). They are characterized by a variety of species, but usually have a low infestation level. The reason is feeding on terrestrial prey, the seasonal visit of water bodies for reproduction and the "mating fasting" of the host. The second group (8) includes adult geohelminths (nematodes). With a smaller number of species, they have a wide distribution, frequent occurrence and a high level of invasion, which is influenced by the lifestyle of the moor frog. The third group (11) includes larval biohelminths (trematodes, cestodes). They occur sporadically and with different infestations depending on the presence of predators of a higher trophic level and the degree of habitat degradation.

The moor frog plays an important biocoenotic role as prey of a number of predators: snakes, owls, crows and diurnal birds of prey, canine and feline mammals. This is evidenced by the presence of larval stages of helminths (cestodes and trematodes). They circulate through trophic levels and complete their development in the body of representatives of these groups of vertebrates. In addition to the definitive hosts, this amphibian species has the ability to transmit mesocercariae and metacercariae of individual trematode species (families Strigeidae, Diplostomidae) a vast number of their reservoir hosts: green frogs, vipers and lizards, ducks, gulls and chickens, rodents, martens, insectivorous and canine mammals, wild boars. These facts indicate the significant role of the moor frog in the circulation of parasites in terrestrial and near-water natural biocoenoses of the Volga river basin. Changes in natural communities can negatively influence the population of $R$. arvalis. A decrease in the number of this species will lead to changes in the circulation of helminths along trophic chains within the ecosystem. In this regard, it is necessary to monitor the impact of climate change on the helminth fauna of $R$. arvalis in different parts of its range.

Author Contributions: Conceptualization, I.V.C.; methodology, I.V.C. and A.B.R.; validation, I.V.C. and A.B.R.; formal analysis, I.V.C. and A.B.R.; investigation, I.V.C.; data curation, I.V.C. and A.B.R.; writing-original draft preparation, I.V.C.; writing—review and editing, I.V.C. and A.B.R. All authors have read and agreed to the published version of the manuscript.

Funding: The research for this paper had no direct external funding to the authors.

Institutional Review Board Statement: All applicable institutional, national, and international guidelines for the care and use of animals were followed. Directive of the European Parliament and 
the Council of the European Union of 22 September 2010 “On the Protection of Animals Used for Scientific Purposes" (EU directive 2010/63/EU).

Acknowledgments: The authors are grateful to the staff of the Institute of Ecology of the Volga basin of the Russian Academy of Sciences (Samara Federal Research Center of the Russian Academy of Sciences, Russia) Alexander I. Fayzulin (Togliatti), Alexander A. Kirillov and Nadezhda Yu. Kirillova (Samara) for their assistance in collecting the material. The research was carried out on the subject of research of the Institute of Ecology of the Volga River Basin of the Russian Academy of Sciences-Branch of the Samara Federal Research Center of the Russian Academy of Sciences AAAA-A17-117112040040-3 "Assessment of modern biodiversity and forecast of its change for the ecosystems of the Volga basin in the conditions of their natural and anthropogenic transformation" (theme 52 "Biological diversity").

Conflicts of Interest: The authors declare no conflict of interest.

\section{Appendix A Annotated List of Rana arvalis Helminths in the Volga River Basin}

Phylum Plathelminthes Schneider, 1873

Class Cestoda Rudolphi, 1808

Order Diphyllobothriidea Kuchta, Scholz, Brabec et Bray, 2008

Family Diphyllobothriidae Lühe, 1910

Spirometra erinacei (Rudolphi, 1918), larvae

Localization: musculature.

Areas of detection: The Republic of Mordovia [127]. It was discovered in the moor frog of the fauna of the Volga basin for the first time.

Biology: Oligohostal parasite of frogs (Ranidae). Trixenic life cycle (Table 2).

Distribution: cosmopolite.

Class Trematoda Rudolphi, 1808

Order Hemiurida Skrjabin et Guschanskaja, 1956

Family Derogenidae Nicoll, 1910

Halipegus ovocaudatus (Vulpian, 1859)

Localization: oral cavity.

Areas of detection: The Republic of Tatarstan [65].

Biology: Polyhostal parasite of anurans (Anura). Tetraxenic life cycle (Table 2).

Distribution: Europe.

Order Paramphistomida Skrjabin et Schulz, 1937

Family Diplodiscidae Cohn, 1904

Diplodiscus subclavatus (Pallas, 1760)

Localization: rectum, small intestine.

Areas of detection: Nizhny Novgorod [66,68,69] and Samara [128-133] regions, the Republics of Mordovia [131,134-138], Tatarstan [64,65] and Bashkortostan [62,63,139-141].

Biology: Polyhostal parasite of amphibians (Amphibia). Dixenic life cycle (Table 2).

Distribution: cosmopolite.

Order Fasciolida Skrjabin et Schulz, 1935

Family Gorgoderidae Looss, 1899

Gorgodera cygnoides (Zeder, 1800)

Localization: bladder.

Areas of detection: The Republics of Mordovia [138], Tatarstan [64] and Bashkortostan $[63,139,140,142,143]$.

Biology: Polyhostal parasite of anurans (Anura). Trixenic life cycle (Table 2). 
Distribution: Palaearctic.

Gorgodera microovata Fuhrmann, 1924

Localization: bladder.

Areas of detection: Nizhny Novgorod region [68], the Republic of Mordovia [135,136,138].

Biology: Oligohostal parasite of frogs (Ranidae). Life cycle is not known. Probably the same as in other trematodes of the Gorgoderidae family.

Distribution: Europe.

Gorgodera pagenstecheri Sinitzin, 1905

Localization: bladder.

Areas of detection: Nizhny Novgorod region [68,69], the Republic of Mordovia [134-136]. Biology: Oligohostal parasite of frogs (Ranidae). Trixenic life cycle (Table 2).

Distribution: Palaearctic.

Gorgodera varsoviensis Sinitzin, 1905

Localization: bladder.

Areas of detection: Samara region [128-130,133,135]. It was discovered in the moor frog of the fauna of Russia and the Volga basin for the first time.

Biology: Oligohostal parasite of frogs (Ranidae). Trixenic life cycle (Table 2).

Distribution: Europe.

Gorgoderina vitelliloba (Olsson, 1876)

Localization: bladder.

Areas of detection: Nizhny Novgorod region [68,69], the Republics of Mordovia [135,136,138] and Bashkortostan [63,139,140,142,143].

Biology: Polyhostal parasite of anurans (Anura). Trixenic life cycle (Table 2).

Distribution: Palaearctic.

Order Plagiorchiida La Rue, 1957

Family Plagiorchiidae Luhe, 1901

Haplometra cylindracea (Zeder, 1800)

Localization: lungs.

Areas of detection: Vologda [144,145], Ivanovo [146], Nizhny Novgorod [67-69], Samara [128-130,132,133,135] and Saratov [131,135] regions, the Republic of Mordovia [131,134-138] and Bashkortostan [63,139-141].

Biology: Oligohostal parasite of frogs (Ranidae). Trixenic life cycle (Table 2).

Distribution: Palaearctic.

Family Telorchiidae Looss, 1899

Dolichosaccus rastellus (Olsson, 1876)

Localization: small intestine.

Areas of detection: Samara [132,133,135] and Saratov [131,135] regions, the Republics of Mordovia [131,134-136] and Bashkortostan [141].

Biology: Oligohostal parasite of frogs (Ranidae). Trixenic life cycle (Table 2).

Distribution: Palaearctic.

Opisthioglyphe ranae (Frohlich, 1791)

Localization: small intestine.

Areas of detection: Nizhny Novgorod [66,67] and Samara [128-133,135] regions, the Republics of Mordovia [138], Tatarstan [65], and Bashkortostan [63,139,140].

Biology: Polyhostal parasite of amphibians (Amphibia). Trixenic life cycle (Table 2).

Distribution: Palaearctic. 
Family Leptophallidae Dayal, 1938

Paralepoderma cloacicola (Luhe, 1909), larvae

Localization: musculature, kidneys.

Areas of detection: Samara $[128-133,135]$ and Saratov $[131,135]$ regions, the Republic of Mordovia [131,134-138].

Biology: Polyhostal parasite of amphibians (Amphibia) at the metacercariae stage. Trixenic life cycle (Table 2).

Distribution: Palaearctic.

Family Haematoloechidae Freitas et Lent, 1939

Haematoloechus (=Pneumonoeces) variegatus (Rudolphi, 1819)

Localization: lungs.

Areas of detection: Ivanovo [146] and Samara $[128,129,131,133,135]$ regions, the Republics of Mordovia [134-136] and Bashkortostan [63,139-141].

Biology: Polyhostal parasite of anurans (Anura). Trixenic life cycle (Table 2).

Distribution: Palaearctic.

Haematoloechus (=Pneumonoeces) asper (Looss, 1899)

Localization: lungs.

Areas of detection: Vologda [144,145] and Nizhny Novgorod [67] regions.

Biology: Oligohostal parasite of frogs (Ranidae). Trixenic life cycle (Table 2).

Distribution: Europe.

Skrjabinoeces similis (Looss, 1899)

Localization: lungs.

Areas of detection: Samara $[131,133,135]$ and Saratov $[131,135]$ regions, the Republic of Bashkortostan [142,143].

Biology: Oligohostal parasite of frogs (Ranidae). Trixenic life cycle (Table 2).

Distribution: Palaearctic.

Order Plagiorchiida La Rue, 1957

Family Pleurogenidae Looss, 1899

Brandesia turgida (Brandes, 1888)

Localization: pouch-like herniations (diverticula) in the wall of the duodenum.

Areas of detection: The Republic of Bashkortostan [63,139,140].

Biology: Oligohostal parasite of frogs (Ranidae). Life cycle is not known.

Distribution: Palaearctic.

Pleurogenes claviger (Rudolphi, 1819)

Localization: small intestine.

Areas of detection: Samara region [131,133,135], the Republics of Mordovia [131,134-137] and Bashkortostan $[62,63,139,140]$.

Biology: Polyhostal parasite of amphibians (Amphibia). Trixenic life cycle (Table 2).

Distribution: cosmopolite.

Pleurogenes intermedius Issaitchikov, 1926

Localization: pouch-like herniations (diverticula) in the wall of the bladder, intestine, and abdominal musculature.

Areas of detection: Samara region [132,133], the Republics of Mordovia [131,134-136, 138] and Bashkortostan [62,63,139-143].

Biology: Oligohostal parasite of frogs (Ranidae). Life cycle is not known.

Distribution: Palaearctic. 
Pleurogenoides medians (Olsson, 1876)

Localization: small intestine.

Areas of detection: Vologda [144,145] and Nizhny Novgorod [66,68,69] regions, the Republics of Mordovia [138] and Bashkortostan [62,63,139-141].

Biology: Polyhostal parasite of anurans (Anura). Trixenic life cycle (Table 2).

Distribution: Palaearctic.

Prosotocus confusus (Looss, 1894)

Localization: stomach, small intestine.

Areas of detection: Nizhny Novgorod [66,68,69] and Samara [128,129,131,133,135] regions, the Republic of Bashkortostan [63,139-141].

Biology: Polyhostal parasite of anurans (Anura). Trixenic life cycle (Table 2).

Distribution: Palaearctic.

Order Strigeidida (La Rue, 1926)

Family Strigeidae Railliet, 1919

Strigea strigis (Schrank, 1788), larvae

Localization: serous coat of inner organs, mesentery, musculature.

Areas of detection: Samara [128,129,131,133,135] and Saratov [131,135] regions, the Republics of Mordovia [131,134-138] and Bashkortostan [141].

Biology: Polyhostal parasite of anurans (Anura) at the mesocercariae and metacercariae stage. Tetraxenic life cycle (Table 2).

Distribution: Palaearctic.

Strigea sphaerula (Rudolphi, 1803), larvae

Localization: serous coat of inner organs, pericardium, mesentery, musculature.

Areas of detection: Samara region [128,129,133], the Republics of Mordovia [131,134138] and Bashkortostan [139-141,147].

Biology: Polyhostal parasite of anurans (Anura) at the mesocercariae and metacercariae stage. Tetraxenic life cycle (Table 2).

Distribution: Europe.

Strigea falconis Szidat, 1928, larvae

Localization: musculature.

Areas of detection: Samara region [133] and the Republic of Mordovia [134-138]. It was discovered in the moor frog of the fauna of Russia and the Volga basin for the first time.

Biology: Polyhostal parasite of anurans (Anura) at the mesocercariae and metacercariae stage. Tetraxenic life cycle (Table 2).

Distribution: cosmopolite.

Family Diplostomidae Poirier, 1886

Neodiplostomum spathoides Dubois, 1937, larvae

Localization: musculature, body cavity, subcutaneous tissue.

Areas of detection: Samara region [128,129,131-133,135] and the Republic of Mordovia [138]. It was discovered in the moor frog of the fauna of Russia and the Volga basin for the first time.

Biology: Oligohostal parasite of frogs (Ranidae) at the metacercariae stage. Trixenic life cycle (Table 2).

Distribution: Palaearctic.

Tylodelphys excavata (Rudolphi, 1803), larvae

Localization: spinal cord canal. 
Areas of detection: Samara region [133]. It was discovered in the moor frog of the fauna of Russia and the Volga basin for the first time.

Biology: Polyhostal parasite of anurans (Ranidae, Discoglossidae) at the metacercariae stage. Trixenic life cycle (Table 2).

Distribution: Palaearctic.

Alaria alata (Goeze, 1782), larvae

Localization: musculature, mesentery, serous coat of the internal organs.

Areas of detection: Samara [128-133,135] and Saratov [131,135] regions, the Republics of Mordovia [131,134-138] and Bashkortostan [63,139-141,147].

Biology: Polyhostal parasite of anurans (Anura) at the mesocercariae stage. Trixenic life cycle (Table 2).

Distribution: cosmopolite.

Pharyngostomum cordatum (Diesing, 1850), larvae

Localization: musculature, mesentery, pericardium, body cavity, stomach, and intestinal walls.

Areas of detection: Samara region $[128,129,131,133,135]$. It was discovered in the moor frog of the fauna of Russia and the Volga basin for the first time.

Biology: Oligohostal parasite of frogs (Ranidae) at the metacercariae stage. Trixenic life cycle (Table 2).

Distribution: Palaearctic.

Incertae sedis group

Astiotrema monticelli Stossich, 1904, larvae

Localization: intestine mesentery.

Areas of detection: Samara region [132,133,135] and the Republic of Mordovia [131,134-136]. It is observed for the first time in moor frog on the territory of Russia and Volga basin.

Biology: Polyhostal parasite of anurans (Anura) at the metacercariae stage. Trixenic life cycle (Table 2).

Distribution: Europe.

Encyclometra colubrimurorum (Rudolphi, 1819), larvae

Localization: body cavity, serous coat of internal organs (liver, spleen, ovary), mesentery.

Areas of detection: Samara $[132,133,135]$ and Saratov $[131,135]$ regions. It was discovered in the moor frog of the fauna of Russia and the Volga basin for the first time.

Biology: Polyhostal parasite of anurans (Ranidae, Pelobatidae) at the metacercariae stage. Trixenic life cycle (Table 2).

Distribution: Palaearctic.

Phylum Nematoda Cobb, 1932

Class Chromadorea Inglis, 1983

Order Panagrolaimida Hodda, 2007

Family Rhabdiasidae Railliet, 1915

Rhabdias bufonis (Schrank, 1788)

Localization: lungs.

Areas of detection: Vologda [144,145], Ivanovo [146], Nizhny Novgorod [66-69], Samara $[128,129,131,133,135]$, and Saratov $[131,135]$ regions, the Republics of Mordovia [131,134-138], Tatarstan [65] and Bashkortostan [62,63,139-143].

Biology: Polyhostal parasite of anurans (Anura). Monoxenic life cycle (geohelminth) (Table 2).

Distribution: Holarctic. 
Family Strongyloididae Chitwood et McIntosh, 1934

Strongyloides spiralis Grabda-Kazubska, 1978

Localization: rectum

Areas of detection: Samara region $[128,129,131,133,135]$. It was discovered in the moor frog of the fauna of Russia and the Volga basin for the first time.

Biology: Oligohostal parasite of frogs (Ranidae). Life cycle is not known.

Distribution: Holarctic.

Family Trichostrongylidae Leiper, 1908

Oswaldocruzia filiformis (Goeze, 1782)

Localization: small intestine.

Areas of detection: Vologda [144,145], Ivanovo [146], Nizhny Novgorod [66-69], Samara [128-133,135] and Saratov [131,135] regions, the Republics of Mordovia [131,134-138], Tatarstan [65], and Bashkortostan [62,63,139-143,147].

Biology: Polyhostal parasite of amphibians (Amphibia). Monoxenic life cycle (geohelminth) (Table 2).

Distribution: Palaearctic. The results of partial sequencing and molecular phylogenetic analysis of CoxI mtDNA gene showed that all Oswaldocruzia species in this study belonged to the same species [119].

Order Spirurida Railliet, 1914

Family Cosmocercidae Travassos, 1925

Aplectana acuminata (Schrank, 1788)

Localization: intestine.

Areas of detection: Vologda [144,145], Ivanovo [146] and Nizhny Novgorod [66] regions, the Republics of Tatarstan [64,65], and Bashkortostan [63,139-141,143].

Biology: Polyhostal parasite of tadpoles, less often-adult anurans (Anura). Monoxenic life cycle (geohelminth) (Table 2).

Distribution: Europe.

Cosmocerca ornata (Dujardin, 1845)

Localization: rectum.

Areas of detection: Vologda [144,145], Ivanovo [146], Nizhny Novgorod [66-69], Samara [128-133,135] and Saratov [131,135] regions, the Republics of Mordovia [131,134-138], Tatarstan [64,65], and Bashkortostan [141-143].

Biology: Polyhostal parasite of amphibians (Amphibia). Monoxenic life cycle (geohelminth) (Table 2).

Distribution: Europe.

Cosmocerca commutata (Diesing, 1851)

Localization: rectum.

Areas of detection: Nizhny Novgorod region [66], the Republics of Tatarstan [64,65], and Bashkortostan $[63,139,140,143]$.

Biology: Monohostal parasite of the green toad (Bufotes viridis Laurenti, 1768). Monoxenic life cycle (geohelminth) with obligatory amphixeny (Table 2).

Distribution: Palaearctic.

Oxysomatium brevicaudatum (Zeder, 1800)

Localization: rectum.

Areas of detection: Nizhny Novgorod region [66-69], the Republics of Mordovia [131,135-137] and Bashkortostan $[63,139,140]$. 
Biology: Polyhostal parasite of amphibians (Amphibia). Monoxenic life cycle (geohelminth) (Table 2).

Distribution: Holarctic.

Neoraillietnema praeputiale (Skrjabin, 1916)

Localization: rectum.

Areas of detection: Nizhny Novgorod region $[66,68,69]$ and the Republic of Mordovia [127].

(Table 2).

Biology: Polyhostal parasite of anurans (Anura). Monoxenic life cycle (geohelminth)

Distribution: Europe.

Family Onchocercidae (Leiper, 1911)

Icosiella neglecta (Diesing, 1851)

Localization: muscles, subcutaneous tissue.

Areas of detection: The Republic of Mordovia [138]. First observed in the moor frog of Russia and the Volga basin.

Biology: Oligohostal parasite of frogs (Ranidae). Dixenic life cycle (Table 2).

Distribution: Palaearctic.

\section{References}

1. Alford, R.A.; Richards, S.J. Global amphibian declines: A problem in applied ecology. Ann. Rev. Ecol. Syst. 1999, 30, 133-165. [CrossRef]

2. Houlahan, J.E.; Findlay, C.S.; Schmidt, B.R.; Meyer, A.H.; Kuzmin, S.L. Quantitative evidence for global amphibian population declines. Nature 2000, 404, 752-755. [CrossRef] [PubMed]

3. Alford, R.A.; Dixon, P.M.; Pechmann, J.H.K. Global amphibian population declines. Nature 2001, 412, 499-500. [CrossRef] [PubMed]

4. Hilton-Taylor, C.; Pollock, C.M.; Chanson, J.S.; Butchart, S.H.M.; Oldfield, T.E.E.; Katariya, V. State of the world's species. In Wildlife in a Changing World: An Analysis of the 2008 IUCN Red List of Threatened Species ${ }^{\mathrm{TM}}$; Vié, J.-C., Hilton-Taylor, C., Stuart, S.N., Eds.; International Union for Conservation of Nature (IUCN): Gland, Switzerland, 2008; pp. 15-41.

5. Vallan, D. Effects of anthropogenic environmental changes on amphibian diversity in the rain forests of eastern Madagascar. J. Trop. Ecol. 2002, 18, 725-742. [CrossRef]

6. Chifundera, K.Z. Using diversity indices for identifying the priority sites for herpetofauna conservation in the Democratic Republic of the Congo. Nat. Conserv. Res. 2019, 4, 13-33. [CrossRef]

7. Kestemont, B. The bottom-up assessment of threatened species. Nat. Conserv. Res. 2019, 4, 93-106. [CrossRef]

8. Kurnaz, M.; Kutrup, B. New distribution data of the vulnerable Mertensiella caucasica from Gümüşhane, Turkey. Nat. Conserv. Res. 2019, 4, 109-111. [CrossRef]

9. Elmajdoub, O.L.; Elhamali, S.H.; Mosaab, O.A.; Afaf, A.M. Prevalence of endo-parasites of common tree frog (Rana saharica) from Misurata, Libya. Sudan J. Med. Sci. 2018, 13, 50-61. [CrossRef]

10. Daszak, P.; Berger, L.; Cunningham, A.A.; Hyatt, A.D.; Green, D.E.; Speare, R. Emerging infectious diseases and amphibian population declines. Emerg. Infect. Dis. 1999, 5, 735-748. [CrossRef]

11. Taylor, S.K.; Williams, E.S.; Thorne, E.T.; Mills, K.W.; Withers, D.I.; Pier, A.C. Causes of mortality of the Wyoming toad. J. Wildl. Dis. 1999, 35, 49-57. [CrossRef]

12. Longcore, J.E.; Pessier, A.P.; Nichols, D.K. Batrachochytrium dendrobatidis gen et sp. nov., a chytrid pathogenic to amphibians. Mycologia 1999, 91, 219-227. [CrossRef]

13. Fellers, G.M.; Green, D.E.; Longcore, J.E. Oral chytridiomycosis in the mountain yellow-legged frog (Rana muscosa). Copeia 2001, 4, 945-953. [CrossRef]

14. Bradley, G.A.; Rosen, P.C.; Sredl, M.J.; Jones, T.R.; Longcore, J.E. Chytridiomycosis in three species of native Arizona frogs (Rana yavapaiensis, Rana chiricauhuensis and Hyla arenicolor). J. Wildl. Dis. 2002, 38, 206-212. [CrossRef]

15. Vershinin, V.L.; Neustroeva, N.S. The role of trematode invasion in the specificity of skeletal morphogenesis in tailless amphibians by the example of Rana arvalis Nilsson, 1842. Proc. Acad. Sci. 2011, 440, 279-281. (In Russian)

16. Johnson, P.T.J.; Lunde, K.B.; Thurman, E.M.; Ritchie, E.G.; Wray, S.N.; Sutherland, D.R.; Kapfer, J.M.; Frest, T.J.; Bowerman, J.; Blaustein, A.R. Parasite (Ribeiroia ondatrae) infection linked to amphibian malformations in the Western United States. Ecol. Monogr. 2002, 72, 151-168. [CrossRef]

17. Wilson, W.D.; Johnson, P.T.J.; Sutherland, D.R.; Moné, H.; Loker, E.S. A molecular phylogenetic study of the genus Ribeiroia (Digenea): Trematodes known to cause limb malformations in amphibians. J. Parasitol. 2005, 91, 1040-1045. [CrossRef] [PubMed] 
18. Johnson, P.T.J.; McKenzie, V.J. Effects of environmental change on helminth infections in amphibians: Exploring the emergence of Ribeiroia and Echinostoma infections in North America. In The Biology of Echinostomes: From the Molecule to the Community; Toledo, R., Fried, B., Eds.; Springer: New York, NY, USA, 2009; pp. 249-280. [CrossRef]

19. Grabda-Kazubska, B. Pleurogenes hepaticola sp. n. (Trematoda, Pleurogenidae), a parasite of the biliary duct of Rana esculenta L. in Poland. Acta Parasitol. Polon. 1972, 20, 45-54.

20. Einszporn-Orecka, T.; Grabda-Kazubska, B. Pathological changes in the bile tract and the liver of Rana esculenta L., infested with trematode Pleurogenes hepaticola Grabda-Kazubska, 1972. Acta Parasitol. Polon. 1973, 21, 501-512.

21. Ivanov, V.M.; Kalmykov, A.P.; Semyonova, N.N.; Fedorovich, V.V.; Parshina, O.Y. Marsh frog behavior and viability changes under the influence of helminthic invasion. Curr. Stud. Herpetol. 2012, 12, 49-55. (In Russian)

22. Vedernikov, A.A.; Svinin, A.O.; Ermakov, O.A.; Chelyadnikova, Y.A.; Musatov, G.A.; Drobot, G.P. Granulomatous inflammations in the intestine of Pelophylax ridibundus (Anura: Ranidae) caused by Brandesia turgida (Plathelminthes: Digenea). Nat. Conserv. Res. 2020, 5, 72-76. [CrossRef]

23. Roček, Z.; Šandera, M. Distribution of Rana arvalis in Europe: A historical perspective. Z. Feldherpetol. 2008, 13, 135-150.

24. Vos, C.C.; Chardon, J.P. Effects of habitat fragmentation and road density on the distribution pattern of the moor frog Rana arvalis. J. Appl. Ecol. 1998, 35, 44-56. [CrossRef]

25. Ibragimova, D.V.; Lyapkov, S.M. Demographic and morphometric characteristics of the moor frog Rana arvalis from a transformed habitat in the Khanty-Mansi Autonomous Region-Yugra. Biol. Bull. 2018, 45, 831-838. [CrossRef]

26. Korzikov, V.A.; Aleksanov, V.V. On some factors driving the presence of amphibians in water bodies of the Upper Oka basin (Central Russia). Nat. Conserv. Res. 2018, 3, 110-119. [CrossRef]

27. Lebedinskii, A.A.; Noskova, O.S.; Dmitriev, A.I. Post-fire recovery of terrestrial vertebrates in the Kerzhensky State Nature Biosphere Reserve (Central Volga Region, Russia). Nat. Conserv. Res. 2019, 4, 45-56. [CrossRef]

28. Berman, D.I.; Bulakhova, N.A.; Meshcheryakova, E.N.; Shekhovtsov, S.V. Overwintering and cold tolerance in the moor frog (Rana arvalis) across its range. Can. J. Zool. 2020, 98, 705-714. [CrossRef]

29. Cedhagen, T. Endoparasites in some Swedish amphibians. Acta Parasitol. Polon. 1988, 33, 107-113.

30. Frandsen, F. A study of Danish amphibians' parasitic fauna. Acta Parasitol. Polon. 1974, 22, 49-66.

31. Paul, D. Beobachtungen über die Darmparasiten schlesischer Anuren. Z. Parasitenk. 1934, 7, 172-197. [CrossRef]

32. Odening, K. Die zooparasiten der frösche deutschlands. Wissenschft. Zeits. Friedrich Schiller Univ. Jena Nat. Nat. Reihe 1958, 5, 179-215.

33. Hartwich, G. Die Tierwelt Deutschlands. I.: Rhabditida und Ascaridida. Mitt. Zool. Mus. Berlin 1975, $62,256$.

34. Grabda-Kazubska, B. Catalogue of Parasite Fauna of Poland. III. Parasites of Amphibian and Reptilies (Katalog Fauny Pasożytnicej Polski. Część III. Pasożyty Płazów i Gadów); Państwowe Wydawnictwo Naukowe: Warszawa-Wrocław, Poland, 1972; p. 112. (In Polish)

35. Kozłowska, J. On the nematodes of amphibians of Poland, mainly from the environment of Łódź. Acta Parasitol. Polon. 1960, 8 , 215-230.

36. Kuc, I.; Sulgostowska, T. Helminth fauna of frogs in the Forest of Kampinos near Warszawa. Acta Parasitol. Polon. 1988, 33, 267-272.

37. Okulewicz, A.; Hildebrand, J.; Łysowski, R.; Buńkowska, K.; Perec-Matysiak, A. Helminth communities of green and brown frogs from Poland (Lower Silesia Region). J. Herpetol. 2014, 48, 34-37. [CrossRef]

38. Sey, O. Studies on the parasitic worms of Hungary I. Trematodes from amphibians and reptiles. In Pécsi Tanárképző Főiskola Tudományos Közleményei; Pécsi Tanárképző Fớiskola: Pécs, Hungary, 1964; Volume 1, pp. 413-437.

39. Vojtková, L.; Moravec, F. Nematodenlarven (Nematoda) aus den Amphibien in der Tschechoslovakei. Scr. Fac. Sci. Nat. Univ. Purk. Brun. 1973, 3, 81-92.

40. Vojtková, L. Trematodes of Amphibians of the CSSR. I. Adult stages (Motolice obojživelníků ČSSR. I. Dospělĕ motolice). Folia Fac. Sci. Nat. Univ. Purk. Brun. 1974, 15, 3-131. (In Czech)

41. Vojtková, L. Nematoda of amphibians of CSSR. I. Adults nematodes. Folia Fac. Sci. Nat. Univ. Purk. Brun. 1976, 55, 5-80. (In Czech)

42. Vojtková, L. Acanthocephales of Amphibians of the Czechoslovakia (Vrtejši (Acanthocephala) obojživelníků Československa). Scr. Fac. Sci. Natur. Univ. Purk. Brun. 1979, 9, 65-78. (In Czech)

43. Vojtková, L. Cestodes of amphibians of the Czechoslovakia (Tasemnice (Cestoda) obojživelníků Československa). Scr. Fac. Sci. Nat. Univ. Purk. Brun. 1980, 10, 473-482. (In Czech)

44. Vojtková, L. The occurrence of the representatives of the class Monogenea in amphibians in Europe. Scr. Fac. Sci. Nat. Univ. Purk. Brun. 1989, 19, 321-338.

45. Vojtková, L.; Vojtek, J. Trematodes of Amphibians of the CSSR. II. Larval stages (Motolice obojživelníků ČSSR. II. Larvální stadia). Folia Fac. Sci. Nat. Univ. Purk. Brun. 1975, 16, 7-84. (In Czech)

46. Ryzhikov, K.M.; Sharpilo, V.P.; Shevchenko, N.N. Amphibian Helminths of the USSR Fauna; Nauka: Moscow, Russia, 1980; p. 279. (In Russian)

47. Merkusheva, I.V. Helminths of Domestic and Wild Animals in Belarus: Catalogue; Nauka i tekhnika: Minsk, Russia, 1981; 120p.

48. Shimalov, V.V. The helminth fauna of amphibians of open channels in meliorated regions of the Belarussian Polesie. Parazitologyia 2002, 36, 304-309. (In Russian) 
49. Shimalov, V.V. The Helminthofauna of amphibians (Vertebrata, Amphibia) and reptiles (Vertebrata, Reptilia) in the Landscape Reserve «Bugskiy» (Belarus). Brest Univ. Bull. 2008, 2, 80-87. (In Russian)

50. Shimalov, V.V. Helminth fauna of amphibians (Vertebrata: Amphibia) in the Republic of Belarus. Parazitologyia 2009, 43, 118-129. (In Russian)

51. Vojtková, L. Research into the parasitofauna in Amphibians in Europe. Part I: Parasitofauna of frogs in the individual countries. Scripta Biol. 1990, 20, 477-493.

52. Vojtková, L.; Roca, V. Parasites of the frogs and toads in Europe. Part II: Trematoda. Rev. Esp. Herp. 1994, 8, 7-18.

53. Vojtková, L.; Roca, V. Parasites of the frogs and toads in Europe. Part III: Nematoda, Cestoda, Acanthocephala, Hirudinea, Crustacea and Insecta. Rev. Esp. Herp. 1996, 10, 13-27.

54. Merilä, J.; Sterner, M. Medicinal leeches (Hirudo medicinalis) attacking and killing adults amphibians. Ann. Zool. Fenn. 2002, 39, 343-346.

55. Litvinov, A.; Korneva, L.; Gerasimov, Y.; Kitaev, A.; Seletkova, E.; Okhapkin, A.; Mineeva, N.; Lazareva, V.; Dvinskikh, S.; Alexevnina, M.; et al. Volga river basin. In Rivers of Europe; Tockner, K., Uehlinger, U., Robinson, C.T., Eds.; Academic Press: London, UK, 2009; pp. 23-57. [CrossRef]

56. Bakiev, A.G.; Kirillov, A.A.; Kirillova, N.Y.; Ruchin, A.B.; Klenina, A.A.; Gorelov, R.A.; Kostina, N.V. Reptile occurrences data in the Volga River basin (Russia). Biodivers. Data J. 2020, 8, e58033. [CrossRef]

57. Bakiev, A.G.; Garanin, V.I.; Gorelov, R.A.; Klenina, A.A. Amphibians and Reptiles of the Volga River Basin: History of Study, Bibliography; Anna: Togliatti, Russia, 2020; p. 322. (In Russian)

58. Chikhlyaev, I.V.; Ruchin, A.B. The helminth fauna study of European common brown frog (Rana temporaria Linnaeus, 1758) in the Volga basin. Acta Parasitol. 2014, 59, 459-471. [CrossRef]

59. Chikhlyaev, I.V.; Ruchin, A.B.; Fayzulin, A.I. Short communication: An overview of the trematodes fauna of pool frog Pelophylax lessonae (Camerano, 1882) in the Volga basin, Russia: 1. Adult stages. Nusant. Biosci. 2018, 10, 256-262. [CrossRef]

60. Chikhlyaev, I.V.; Ruchin, A.B.; Fayzulin, A.I. Short communication: An overview of the trematodes fauna of pool frog Pelophylax lessonae (Camerano, 1882) in the Volga basin, Russia: 2. Larval stages. Nusant. Biosci. 2019, 11, 106-111. [CrossRef]

61. Chikhlyaev, I.V.; Ruchin, A.B.; Fayzulin, A.I. Parasitic nematodes of pool frog (Pelophylax lessonae) in the Volga basin. J. MVZ Cordoba 2019, 24, 7314-7321. [CrossRef]

62. Ayupov, K.V.; Valiullin, S.M.; Khaziev, G.Z.; Bayanov, M.G.; Kazadaev, V.I.; Antonov, P.P. Helminths of animals, humans and plants in the Bashkir ASSR. In Helminths of Animals, Humans and Plants in the Southern Urals; Publishing House of BF USSR Academy of Sciences: Ufa, Russia, 1974; Volume 1, pp. 8-28. (In Russian)

63. Bayanov, M.G. Helminths of amphibians in Bashkortostan. In Problems of Animal Ecology of Southern Ural; Chief Department of VINITI, No. 587-B92; Publishing House of Bashkir State University: Ufa, Russia, 1992; Volume 5, pp. 2-10. (In Russian)

64. Shaldybin, S.L. To the parasitic fauna of anurans in Volga-Kama Nature Reserve. In Questions of Herpetology; Nauka: Leningrad, Russia, 1977; pp. 228-230. (In Russian)

65. Smirnova, M.I.; Gorshkov, P.K.; Sizova, V.G. Helminth Fauna of Tailless Amphibians in Tatarstan Republic; Institute of Biology of Academy of Sciences of the USSR: Kazan, Russia, 1987; p. 19. (In Russian)

66. Borisova, V.I. Helminths of amphibians geographical distribution study. Parasitologyia 1988, 22, 471-475. (In Russian)

67. Lebedinskii, A.A.; Golubeva, T.V.; Anisimov, V.I. Some features of brown frogs helminth fauna in conditions of anthropogenic impact. In Fauna and Ecology of Invertebrates; Gorky State Pedagogical University: Gorky, Russia, 1989; pp. 41-46. (In Russian)

68. Nosova, K.F. To the cadastral characteristics of the helminth fauna of a frog in the Gorky region. In All-Union Meeting on the Problem of Cadastre and Accounting of Fauna; Experience of Cadastral Characteristics; Materials for the Cadastre of Invertebrate Animals; Bashkir Book Publishing House: Ufa, Russia, 1989; Volume 4, pp. 314-315. (In Russian)

69. Nosova, K.F. Helminths of Anurans in Lake Ecosystems of the Middle Belt of the European Part of the RSFSR. Ph.D. Thesis, Gorky State Pedagogical University, Gorky, Russia, 1990; p. 173. (In Russian).

70. Sudarikov, V.E.; Shigin, A.A.; Kurochkin, Y.V.; Lomakin, V.V.; Stenko, R.P.; Yurlova, N.I. Metacercariae of Trematodes-Parasites of Freshwater Aquatic Organisms in Central Russia; Nauka: Moscow, Russia, 2002; p. 298. (In Russian)

71. Tkach, V.V.; Pawlowski, J.; Mariaux, J.; Swiderski, Z. Molecular phylogeny of the suborder Plagiorchiata and its position in the system of Digenea. In Interrelations of the Platyhelminthes; Littlewood, D.T.J., Bray, R.A., Eds.; Taylor \& Francis: London, UK, 2001; pp. 186-193.

72. Gibson, D.I.; Jones, A.; Bray, R.A. (Eds.) Keys to the Trematoda; CABI Publishing and London; The Natural History Museum: Wallingford, UK, 2002; Volume 1, p. 521.

73. Gibson, D.I.; Jones, A.; Bray, R.A. (Eds.) Keys to the Trematoda; CABI Publishing and London; The Natural History Museum: Wallingford, UK, 2008; Volume 3, p. 848.

74. Olson, P.D.; Cribb, T.H.; Tkach, V.V.; Bray, R.A.; Littlewood, D.T.J. Phylogeny and classification of the Digenea (Platyhelminthes: Trematoda). Int. J. Parasitol. 2003, 33, 733-755. [CrossRef]

75. Hodda, M. Phylum Nematoda Cobb, 1932. In Animal Biodiversity: An Outline of Higher-Level Classification and Survey of Taxonomic Richness (Zootaxa 3148); Zhang, Z.-Q., Ed.; Magnolia Press: Auckland, New Zealand, 2011; pp. 63-95.

76. Fauna Europaea. Available online: https://fauna-eu.org/cdm_dataportal/search/results/taxon?ws=portal\%2Ftaxon\%2Ffind\& query=Spirometra\&form_build_id=form-tv7mPn4ifvK_8VGsGEK32g01XxEYIEFvJEwk_-eACaQ\&form_id=cdm_dataportal_ 
search_taxon_form\&search\%5BdoTaxaByCommonNames \%5D=\&search\%5BdoSynonyms\%5D=\&search\%5BdoTaxa \%5D=1\& search $\% 5 B$ pageSize $\% 5 \mathrm{D}=25 \&$ search $\% 5$ BpageNumber\%5D=0 (accessed on 16 November 2020).

77. Dubinina, M.N. On biology and distribution of Diphyllobothrium erinacei-europaei (Rud., 1819) Iwata, 1933. Zool. Zhurnal 1951, 30, 421-429. (In Russian)

78. Kechemir, N. Cycle a quatre hotes obligatoires du trematode hemiuride Halipegus ovocaudatus. Bull. Soc. Zool. France 1976, 101, 1061-1062.

79. Skrjabin, K.I. Suborder Paramphistomatata (Szidat, 1936) Skrjabin et Schulz, 1937 In Trematodes of Animals and Humans. Basics of Trematodology; Skrjabin, K.I., Ed.; Publishing House of the USSR Academy of Sciences: Moscow-Leningrad, Russia, 1949; Volume 3, p. 624. (In Russian)

80. Grabda-Kazubska, B. Observations on the life cycle of Diplodiscus subclavatus (Pallas, 1760) (Trematoda, Diplodiscidae). Acta Parasitol. Polon. 1980, 27, 261-271.

81. Pigulevsky, S.V. The family Gorgoderidae Looss, 1901. In Trematodes of Animals and Human. Basics of Trematodology; Skrjabin, K.I., Ed.; Publishing House of the USSR Academy of Sciences: Moscow-Leningrad, Russia, 1952; Volume 7, Part 1; pp. 605-760. (In Russian)

82. Pigulevsky, S.V. The family Gorgoderidae Looss, 1901. In Trematodes of Animals and Human. Basics of Trematodology; Skrjabin, K.I., Ed.; Publishing House of the USSR Academy of Sciences: Moscow-Leningrad, Russia, 1953; Volume 8, Part 2; pp. $251-615$. (In Russian)

83. Kalabekov, A. Development cycles of some trematodes of longlegged wood frog (Rana macrocnemis Boul.). In Ecology and Biology of Animals on the Northern Slopes Central Caucasus; Collection of Zoological Works; Naniev, V.I., Ed.; North Ossetian State University: Ordzhonikidze, Russia, 1976; pp. 3-42. (In Russian)

84. Grabda-Kazubska, B. Studies on the life-cycle of Haplometra cylindracea (Zeder, 1800) (Trematoda, Plagiorchiidae). Acta Parasitol. Polon. 1970, 18, 497-512.

85. Dobrowolsky, A.A.; Raikhel, A.S. The life cycle of Haplometra cylindracea Zeder, 1800 (Trematoda, Plagiorchiidae). Leningr. Univ. Bull. 1973, 3, 5-13. (In Russian)

86. Grabda-Kazubska, B. Studies on abbreviation of the life-cycle in Opisthioglyphe ranae (Froelich, 1791) and O. rastellus (Olsson, 1876) (Trematoda, Plagiorchiidae). Acta Parasitol. Polon. 1969, 16, $20-27$.

87. Dobrowolsky, A.A. Some information about the life cycle of the trematode Opisthioglyphe ranae (Froelich, 1791) (Plagiorchiidae). Helminthologia 1965, 3, 205-221.

88. Dobrowolsky, A.A. The life cycle of Paralepoderma cloacicola (Lühe, 1909) Dollfus, 1950 (Trematoda, Plagiorchiidae). Leningr. Univ. Bull. 1969, 9, 28-38. (In Russian)

89. Grabda-Kazubska, B. A study of the trematode genus Paralepoderma Dollfus, 1950 (Trematoda: Plagiorchiidae). Acta Parasitol. Polon. 1975, 23, 463-484.

90. Skrjabin, K.I.; Antipin, D.N. Superfamily Plagiorchioidea Dollfus, 1930. In Trematodes of Animals and Human. Basics of Trematodology; Skrjabin, K.I., Ed.; Nauka: Moscow, Russia, 1962; Volume 20, pp. 49-166. (In Russian)

91. Thiel, P.H. Die Entwicklung von Agamodistomum anopheles zum Pneumonoeces variegatus Rud. Zentralbl. Bakter. 1930, 117, 103-112.

92. Dobrowolsky, A.A. The life cycle of Pneumonoeces asper Looss, 1899 (Plagiorchiidae, Pneumonoecinae). In Proceedings of the Scientific Conference of the All-Union Society of Helminthologists, Moscow, Russia, December 1965; USSR Academy of Sciences Publishing House: Moscow, Russia, 1965. Part 4. pp. 59-64. (In Russian).

93. Grabda, B. Life cycle of Haematoloechus similis (Looss, 1899) (Trematoda: Plagiorchidae). Acta Parasitol. Polon. 1960, 8, 357-366.

94. Khotenovsky, I.A. The family Pleurogenidae Looss, 1899. In Trematodes of Animals and Human. Basics of Trematodology; Skrjabin, K.I., Ed.; Nauka: Moscow, Russia, 1970; Volume 23, pp. 136-297. (In Russian)

95. Grabda-Kazubska, B. Life cycle of Pleurogenes claviger (Rudolphi, 1819) (Trematoda: Pleurogenidae). Acta Parasitol. Polon. 1971, 19, 337-348.

96. Neuhaus, W. Entwicklung und Biologie von Pleurogenoides medians Olss. Zool. Yahrb. Syst. 1940, 74, $207-242$.

97. Shevchenko, N.N.; Vergun, G.I. On the life cycle of amphibian trematodes Prosotocus confusus (Looss, 1894) Looss, 1899. Helminthologia 1961, 3, 294-298.

98. Sudarikov, V.E. Order Strigeidida (La Rue, 1926) Sudarikov, 1959. In Trematodes of Animals and Human. Basics of Trematodology; Skrjabin, K.I., Ed.; USSR Academy of Sciences Publishing House: Moscow, Russia, 1959; Volume 16, Part 1; pp. $219-631$. (In Russian)

99. Sudarikov, V.E. The biology of trematodes Strigea strigis (Schr., 1788) and S. sphaerula (Rud., 1803). In Works of the Helminthology Laboratory of the USSR Academy of Sciences (GELAN); USSR Academy of Sciences Publishing House: Moscow, Russia, 1960; Volume 10, pp. 217-226. (In Russian)

100. Odening, K. Der Lebenszyklus des Trematoden Strigea strigis (Schrank) im Raum Berlin. Monatsber. Deutsch. Acad. Wissensch. Berlin 1966, 8, 696-697.

101. Odening, K. Die lebenszyklen von Strigea falconispalumbi (Viborg), S. strigis (Schrank) und S. sphaerula (Rudolphi) (Trematoda, Strigeida) im Raum Berlin. Zool. Yahrb. Syst. 1967, 94, 1-67.

102. Odening, K. Der Lebenszyklus des Trematoden Strigea sphaerula (Rudolphi) im Raum Berlin. Monatsber. Deutsch. Acad. Wissensch. Berlin 1966, 8, 695-696. 
103. Heneberg, P.; Sitko, J.; Těšínskýa, M.; Rządc, I.; Bizosa, J. Central European Strigeidae Railliet, 1919 (Trematoda: Strigeidida): Molecular and comparative morphological analysis suggests the reclassification of Parastrigea robusta Szidat, 1928 into Strigea Abildgaard, 1790. Parasitol. Int. 2018, 67, 688-701. [CrossRef]

104. Santoro, M.; Mattiucci, S.; Nascetti, G.; Kinsella, J.M.; Di Prisco, F.; Troisi, S.; D’Alessio, N.; Veneziano, V.; Aznar, F.J. Helminth communities of owls (Strigiformes) indicate strong biological and ecological differences from birds of prey (Accipitriformes and Falconiformes) in Southern Italy. PLoS ONE 2012, 7, e53375. [CrossRef]

105. Sudarikov, V.E. Order Strigeidida (La Rue, 1926) Sudarikov, 1959. In Trematodes of Animals and Human. Basics of Trematodology; Skryabin, K.I., Ed.; USSR Academy of Sciences Publishing House: Moscow, Russia, 1960; Volume 17, Part 2; pp. 157-533. (In Russian)

106. Odening, K. Der Lebenszyklus von Neodiplostomum spathoides Dubois (Trematoda, Strigeida) im Raum Berlin nebst Baitragen zur Entwicklungsweise verwandter Arten. Zool Yahrb. Syst. 1965, 92, 523-624.

107. Odening, K. Die Lebenszyklen der Trematoda Neodiplostomum spathoides Dubois und N. attenuatum (v. Linstow) im Raum Berlin. Monatsber. Deutsch. Acad. Wissensch. Berlin 1965, 7, 952-954.

108. Sitko, J.; Heneberg, P. Unconventional support for a raptorial niche division between Australaves and Afroaves: The distribution of helminthes. Parasitol. Int. 2019, 72, 101946. [CrossRef] [PubMed]

109. Potekhina, L.F. The development cycle of alariosis pathogen in foxes and dogs. Rep. USSR Acad. Sci. 1951, 76, 325-327. (In Russian)

110. Sudarikov, V.E. Biological features of trematodes of the genus Alaria. In Works of the Helminthology Laboratory of the USSR Academy of Sciences (GELAN); USSR Academy of Sciences Publishing House: Moscow, Russia, 1959; Volume 9, pp. 326-332. (In Russian)

111. Sudarikov, V.E. Suborder Strigeata La Rue, 1926. Superfamily Diplostomatoidea Nicoll, 1937. In Trematodes of Animals and Human. Basics of Trematodology; Skryabin, K.I., Ed.; USSR Academy of Sciences Publishing House: Moscow, Russia, 1960; Volume 18, pp. 453-694. (In Russian)

112. Sudarikov, V.E.; Lomakin, V.V.; Semenova, N.N. The trematode Pharyngostomum cordatum (Alariidae, Hall et Wigdor, 1918) and its life cycle under the conditions of the Volga delta. In Helminths of Animals, Works of the Helminthology laboratory of the USSR Academy of Sciences (GELAN); Nauka: Moscow, Russia, 1991; Volume 38, pp. 142-147. (In Russian)

113. Shevchenko, N.N.; Vergun, G.I. Deciphering the cycle of development of trematode Astiotrema monticelli Stossich, 1904. Rep. USSR Acad. Sci. 1960, 130, 949-952. (In Russian)

114. Sharpilo, V.P. Parasitic Worms of Reptile Fauna of the USSR; Naukova Dumka: Kyiv, Russia, 1976; p. 286. (In Russian)

115. Schaake, M. Infectionsmodus und infectionsweg der Rhabdias bufonis Schrank (Angiostomum nigrovenosum) und die metamorphose des genitalapparaten der hermafroditischen generation. Z. Parasitenk. 1931, 3, 517-648. [CrossRef]

116. Savinov, V.A. Some new experimental data on the reservoir parasitism of nematodes. In Proceedings of the Scientific Conference of the All-Union Society of Helminthologists, Moscow, Russia, 9-12 December 1963; USSR Academy of Sciences Publishing House: Moscow, Russia, 1963. Part 2. pp. 73-75. (In Russian).

117. Hendrix, W.M.L. Observations of the routes of infection of Oswaldocruzia filiformis (Nematoda, Trichostrongylidae) in amphibian. Z. Parasitenk. 1983, 69, 119-126. [CrossRef]

118. Moravec, F.; Vojtkova, L. Variabilität von zwei Nematodenarten Oswaldocruzia filiformis (Goeze, 1782) und Oxysomatium brevicaudatum (Zeder, 1800). In Der Gemeinsamen Parasiten der Europäischen Amphibien und Reptilien; Scripta Facultatis Scientiarum Naturalium Universitatis Purkynianae Brunensis, Biologia; Universita J. E. Purkynĕ: Brno, Czechoslovakia, 1975; Volume 2, pp. 61-76.

119. Kirillova, N.Y.; Kirillov, A.A.; Shchenkov, S.V.; Chikhlyaev, I.V. Oswaldocruzia filiformis sensu lato (Nematoda: Molineidae) from amphibians and reptiles in European Russia: Morphological and molecular data. Nat. Conserv. Res. 2020, 5, 41-56. [CrossRef]

120. Kirillov, A.A.; Kirillova, N.Y. Analysis of the reproductive structure of the hemipopulation of the Cosmocerca ornata (Dujardin, 1845) (Nematoda: Cosmocercidae) in marsh frogs of different ages. Inland Water Biol. 2016, 9, 310-318. [CrossRef]

121. Kirillova, N.Y.; Kirillov, A.A. To study of life circle of amphibian parasite Cosmocerca ornata (Nematoda: Cosmocercidae). In Environmental Collection 6, Proceedings of Young Scientists of the Volga Region, Togliatti, Russia, 14-16 March 2017; Senator, S.A., Mukhortova, O.V., Saxonov, S.V., Eds.; Cassandra: Togliatti, Russia, 2017; pp. 192-194. (In Russian)

122. Skrjabin, K.I.; Shikhobalova, N.P.; Lagodovskaya, E.A. Basics of Nematodology. Volume 10. Oxyuridae of Animals and Humans. Part 2; Skrjabin, K.I., Ed.; USSR Academy of Sciences Publishing House: Moscow, Russia, 1961; p. 500. (In Russian) 
123. Yumagulova, G.R. To the study of nematode Cosmocercoides skrjabini (Ivanitzky, 1940). In Results of Biological Research of the Bashkir State University for 1998; Bashkir State University: Ufa, Russia, 1999; pp. 12-13.

124. Desportes, C. Forcipomyia velox Winn et Sycorax silacea Curtis, vecteurs d'Icosiella neglecta (Diesing, 1850) filaire commune de la grenouille verte. Ann. Parasit. Hum. Comp. 1942, 19, 53-68. [CrossRef]

125. Sonin, M.D. Basics of nematodology. In Filarias of Animals and Humans and the Diseases Caused by Them. Part 2. Diplotrienoids; Skrjabin, K.I., Ed.; Nauka: Moscow, Russia, 1968; Volume 21, p. 392. (In Russian)

126. Ruchin, A.; Artaev, O.; Sharapova, E.; Ermakov, O.; Zamaletdinov, R.; Korzikov, V.; Bashinsky, I.; Pavlov, A.; Svinin, A.; Ivanov, A.; et al. Occurrence of the amphibians in the Volga, Don River basins and adjacent territories (Russia): Research in 1996-2020. Biodivers. Data J. 2020, 8, e61378. [CrossRef]

127. Chikhlyaev, I.V.; (Institute of Ecology of Volga River Basin of RAS, Togliatti, Russia). Personal communication, 2019.

128. Evlanov, I.A.; Kirillov, A.A.; Chikhlyaev, I.V.; Guzova, N.Y.; Zhiltsova, L.V. Parasites of Vertebrates of the Samara Region. Part 1: A Systematic Catalog; Institute of Ecology of the Volga River Basin RAS: Togliatti, Russia, 2001; p. 75. (In Russian)

129. Evlanov, I.A.; Kirillov, A.A.; Chikhlyaev, I.V.; Guzova, N.Y.; Zhiltsova, L.V. Parasites of Vertebrates of the Samara Region. Part 2: Distribution of Parasites by Hosts; Institute of Ecology of the Volga River Basin RAS: Togliatti, Russia, 2002; p. 20. (In Russian)

130. Chikhlyaev, I.V. About helminths of the moor frog Rana arvalis Nilsson, 1842 in Samara City. In Modern Zoological Research in Russia and Neighboring Countries, Proceedings of the First International Scientific-Practical Conference Devoted to the 75th Anniversary of M.A. Kozlov, Cheboksary, Russia, 27 April 2011; Dmitriev, A.V., Egorov, L.V., Eds.; New Time: Cheboksary, Russia, $2011 ;$ pp. 80-82. (In Russian)

131. Ruchin, A.B.; Chikhlyaev, I.V.; Lukijanov, S.V. Analysis of helminthofauna of the common spaedfoot Pelobates fuscus (Laurenti, 1768) and the moor frog Rana arvalis Nilsson, 1842 (Amphibia: Anura) at their joint habitation. Parasitologyia 2009, 43, 240-247. (In Russian)

132. Kirillov, A.A.; Chikhlyaev, I.V. Helminthofauna of the lower terrestrial vertebrates (Amphibia, Reptilia) of the Sok River floodplain. In Peculiarities of Freshwater Ecosystems of the Small Rivers of the Volga Basin; Rozenberg, G.S., Zinchenko, T.D., Eds.; Cassandra: Togliatti, Russia, 2011; pp. 178-184. (In Russian)

133. Kirillov, A.A.; Kirillova, N.Y.; Chikhlyaev, I.V. Parasites of Vertebrate Animals of the Samara Region; Evlanov, I.A., Sokolov, S.G., Eds.; Poliar: Togliatti, Russia, 2018; p. 304. (In Russian)

134. Ruchin, A.B.; Chikhlyaev, I.V.; Lukiyanov, S.V.; Ryzhov, M.K. Biology of the moor frog Rana arvalis in Mordovia. Message 3. Helminths and predators. Biol. Kazakhstan 2008, 3, 12-20. (In Russian)

135. Ruchin, A.B.; Chikhlyaev, I.V. To the helminth fauna of the moor frog Rana arvalis Nilsson, 1842 (Amphibia: Anura) from different habitats. Curr. Stud. Herpetol. 2012, 12, 61-68. (In Russian)

136. Ruchin, A.B.; Chikhlyaev, I.V. The helmintofauna of Rana arvalis Nilsson, 1842 (Amphibia: Anura) in the Republic of Mordovia. Russ. J. Parasitol. 2013, 3, 27-34. (In Russian)

137. Ruchin, A.B.; Chikhlyaev, I.V. A helminthofauna study of Rana arvalis Nilsson, 1842 and Rana temporaria Linnaeus, 1758 (Amphibia: Anura) under cohabitation. Curr. Stud. Herpetol. 2013, 13, 130-136. (In Russian)

138. Chikhlyaev, I.V.; Ruchin, A.B.; Fayzulin, A.I. Helminths of tailless amphibians (Anura, Amphibia) of the Mordovia Reserve. In Proceedings of the Mordovia State Nature Reserve; Mordovia State Nature Reserve Named after P.G. Smidovich: Saransk/Pushta, Russia, 2015; Volume 14, pp. 376-388. (In Russian)

139. Yumagulova, G.R. Helminths of Amphibians of the Southern Urals. Ph.D. Thesis, Bashkir State University, Ufa, Russia, 2000. (In Russian).

140. Bayanov, M.G.; Yumagulova, G.R. Helminths of tailless amphibians from various habitat. Results Biol. Res. 2000, 6, 153-155. (In Russian)

141. Chikhlyaev, I.V. About the helminths of the moor frog Rana arvalis Nilsson, 1842 (Amphibia, Anura) on the border of the "Bashkiria" National Park. In Nature, Science and Tourism, Proceedings of the All-Russian Scientific-Practical Conference Dedicated to the 30th Anniversary of the "Bashkiria" National Park, Nugush, Russia, 30 September-1 October 2016; Saifullina, N.M., Ed.; Gilem: Ufa, Russia, 2016; pp. 233-239. (In Russian)

142. Zaripova, F.F. Ecological and Faunistic Characteristics of Amphibious Urban Territories of the Republic of Bashkortostan. Ph.D. Thesis, Institute of Ecology of the Volga River Basin RAS, Togliatti, Russia, 2012; p. 209. (In Russian).

143. Zaripova, F.F.; Faizulin, A.I. Helminths of the moor frog Rana arvalis Nilsson, 1842 urbanized territories of Southern Urals (Republic of Bashkortostan). In Modern Problems of Parasitology and Ecology. Readings Devoted to the Memory of S.S. Shulman, Proceedings of the All-Russian Conference with International Participation, Togliatti, Russia, 15-17 May 2018; Kirillov, A.A., Kirillova, N.Y., Eds.; Poliar: Togliatti, Russia, 2018; pp. 113-121. (In Russian)

144. Radchenko, N.M.; Shabunov, A.A. Ecological and helminthological research of amphibians in the Vologda region. In Parasitology in the XXI Century - Problems, Methods, Solutions, Proceedings of the IV All-Russian Congress of the Parasitological Society, St. Petersburg, Russia, 20-25 October 2008; Galaktionov, K.V., Dobrowolsky, A.A., Eds.; Lema: St. Petersburg, Russia, 2008; Volume 3, pp. 72-75. (In Russian)

145. Shabunov, A.A.; Radchenko, N.M. Parasites of Fish, Amphibians and Gulls in the Ecosystems of Large Water Bodies in the Vologda Region; Vologda State Technical University: Vologda, Russia, 2012; p. 243. (In Russian)

146. Kirillova, Y.A. Helminth Fauna of Tailless Amphibians of the Order Anura in Central Non-Chernozem Zone of Russian Federation. Ph.D. Thesis, Ivanovo State University, Ivanovo, Russia, 2002; p. 145. (In Russian). 
147. Khabibullin, V.F. To the comparative characteristic of the helminth fauna of the grass snake (Natrix natrix) and the moor frog (Rana arvalis). In Fundamental and Applied Problems of Population Biology, Proceedings of the All-Russian Conference, Nizhny Tagil, Russia, 2-6 December 2002; Ural State Pedagogical University: Nizhny Tagil, Russia, 2002; pp. 187-188. (In Russian) 